\title{
ENERGY BUDGETS OVER VARIOUS TYPES OF TERRAIN IN POLAR REGIONS
}

by

\author{
G. Weller and G. Wendler
}

(Geophysical Institute, University of Alaska, Fairbanks, AK 99775-0800, U.S.A.)

\section{ABSTRACT}

This paper summarizes typical energy-balance data for a variety of polar terrain types, to aid in a better understanding of climate and climate change. Terrain types examined include closed boreal forests, open woodlands, tundra, the pack ice of the Arctic Ocean, glaciers and large ice sheets. For each of these terrains energy-balance-related parameters, including albedo, surface roughness, and thermal diffusivity of the subsurface and their seasonal variations are considered. Components of the surface energy balance, and particularly the net radiation or radiation balance, are presented on a seasonal basis. Net radiation is shown to be a poor indicator of climate, if used as the sole parameter, contradicting earlier conclusions by some climatologists. Large differences are shown between the energy balances of the various terrains in summer, with the boreal forest and the tundra acting as major heat sources for the surrounding terrains, and the glaciers acting as major heat sinks. In winter, thin pack ice is the major source of heat energy. These factors not only affect the regional climates of the Arctic, but influence global climate through feedback processes.

\section{INTRODUCTION}

The net loss of energy in the polar regions (the so called polar heat sink) is a key factor in the global energy balance and the global patterns of surface temperature. To understand global processes and global climate changes, which programs such as the International GeosphereBiosphere Program (IGBP) or the U.S. Global Change and Earth System Science program propose to attempt, questions like the following have to be answered: How does the atmosphere at lower latitudes respond to changes of the polar heat sink, and what are the positive and negative feedback processes through which changes in the dynamics and heat balance of the polar atmosphere are transferred to the global atmosphere?

Before answers to these questions are attempted, the highly variable nature of the polar heat budget, both spatially and temporally, must be described. It is the purpose of this paper to do so, based in part on data which the authors have collected themselves in both the Arctic and Antarctic over various terrain types.

Figure 1 shows the location and areal extent of the major terrain types north of the Arctic Circle; similar descriptions for the Antarctic have been given by Weller (1980). The Arctic Ocean covers almost $60 \%$ of this area, most of which is ice-covered in winter. Only a small area off the coast of Scandinavia stays open year-round due to the influence of the Gulf Stream. Tundra is the typical land form normally associated with a polar climate and northern Eurasia and Alaska/Arctic Canada contribute to this area about evenly ( $16.5 \%$ total). Boreal forests cover $13.5 \%$ of the area; they are the dominant surface cover south of the Arctic Circle and penetrate north of the Arctic Circle mostly in Eurasia and to a lesser extent in North America. Glaciers cover $11.2 \%$ of the area north of the Arctic Circle. The Greenland ice sheet is by far the largest component,

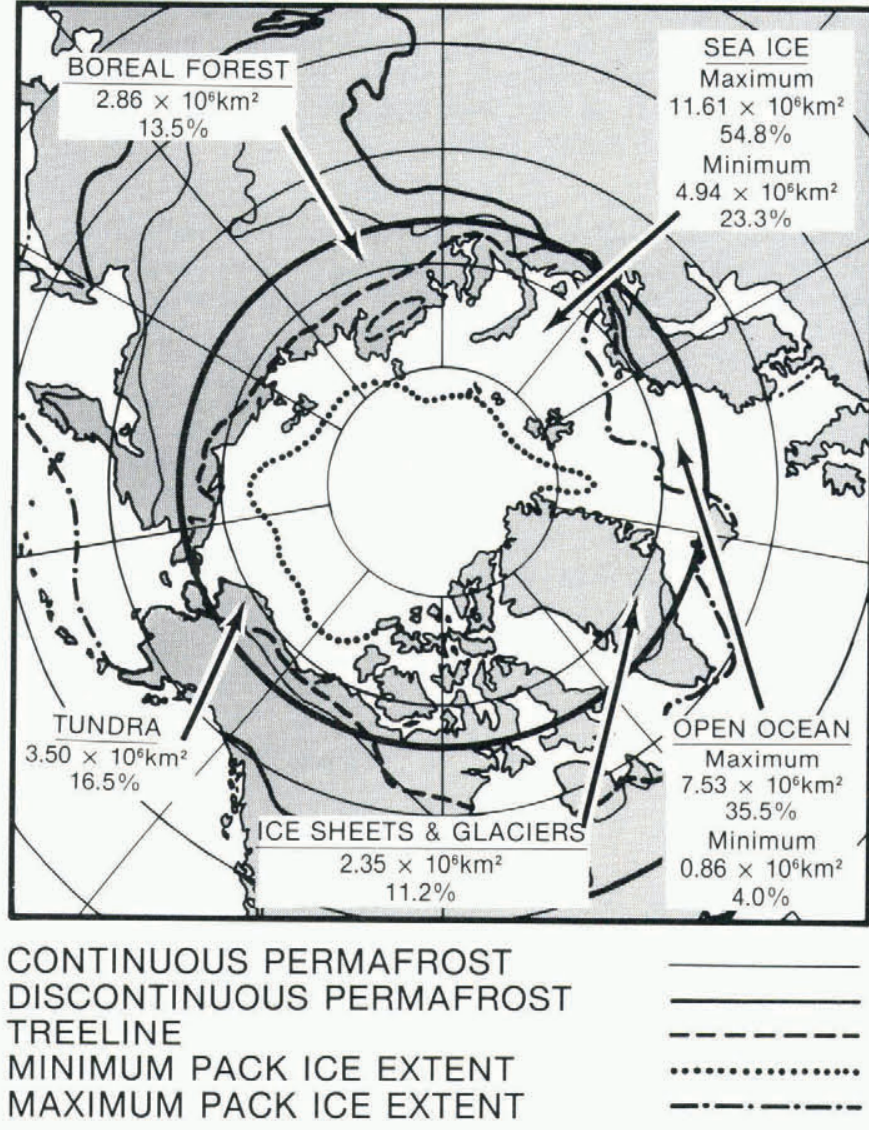

Fig. 1. Locations and areal extent of the major terrain types north of the Arctic Circle.

although there are numerous mountain glaciers and small ice caps in northern Alaska, the Queen Elizabeth Islands, Svalbard, Novaya Zemlya, and northern Scandinavia.

\section{THE ENERGY BALANCE AS AN INDICATOR OF CLIMATE}

The energy balance of any terrestrial surface is usually written as

$$
\mathrm{N}+\mathrm{S}+\mathrm{L}+\mathrm{G}+\mathrm{M}=0
$$

where $\quad \mathrm{N}=$ Net radiation (radiation balance)

$\mathrm{S}=$ Sensible heat flux

$\mathrm{L}=$ Latent heat flux

$\mathrm{G}=$ Subsurface heat flux

$M=$ Heat for melting.

The net radiation $\mathrm{N}$ is the sum of the shortwave and longwave radiation balances. Since $\mathrm{N}$ is also of ten the most 


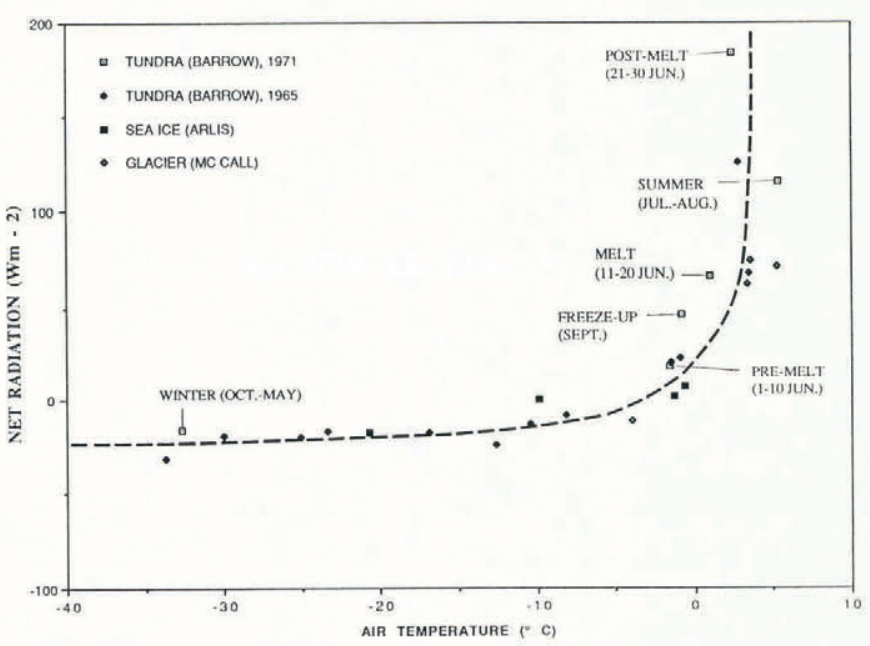

Fig. 2. Relationship between net radiation and air temperature for the seasonal phases of the climate of the coastal tundra at Barrow, Alaska in 1971 and between monthly means of net radiation and air temperature for various Arctic terrain types.

important heat source at the surface under consideration, it is tempting to use it as the sole energy-balance parameter to deduce or explain the climate in the vicinity of that surface (Schwerdtfeger, 1984).

Figure 2 plots the relationship between net radiation and air temperature for various seasons in 1971 in the coastal tundra zone, at Barrow, Alaska, to test this hypothesis. The data are from Weller and Holmgren (1974) for various distinct energy-balance phases. Monthly means of net radiation and air temperature are also compared for other polar surfaces including sea ice (Roulet, 1969), an Arctic glacier (Wendler and Weller, 1974) and the Arctic tundra in 1965 (Weaver, 1969). It is clear from Figure 2 that net radiation cannot be used solely as a good indicator of air temperature in summer. The reason for the poor correlation is that the available heat energy is mostly used up in melting snow and evaporating water, and not to heat the air and therefore raise the temperature.

To understand and explain regional climate and its variability, it is necessary to examine all the terms of the energy balance. Table I shows these terms for summer and winter, and Figure 3 shows graphically some of the differences in the energy balance of various terrain types. On Arctic forests and tundra, snow has completely disappeared by early summer, and the underlying surface has a low albedo and absorbs large quantities of shortwave radiation. Melting occurs earlier in the boreal forests and the net radiation for summer is about twice that of Arctic tundra, where melting starts much later. The radiation budget for the central Arctic Ocean is even lower; there sea ice remains year-round, although the surface is wet and is covered with numerous melt puddles. At higher altitudes, glaciers such as the McCall Glacier in the Brooks Range of northern Alaska, begin to melt even later and the radiation budget is still lower. For the Arctic, north of the treeline, it is the tundra which acts as the major source of heat energy for all the surrounding terrain types.

In the Antarctic, summer conditions are quite different. There are very few exposed rock surfaces and no tundra. Also, melting of snow and ice takes place only in a relatively narrow coastal region. The albedo remains high everywhere and as a consequence the radiation budget is quite low in summer. Nowhere is this more apparent than on the slopes and the plateau of the Antarctic ice sheet, where no melting occurs at all and the radiation budget is

TABLE I. ENERGY BALANCE OVER VARIOUS TYPES OF TERRAIN IN POLAR REGIONS

Energy balance

$\mathrm{W} \mathrm{m}^{-2}$

Terrain type

Arctic

Snow-free in summer Closed forest,
$60^{\circ} \mathrm{N}$, NWT

Open woodland,

$63^{\circ} \mathrm{N}$, NWT

and Alaska

Coastal tundra,

$71^{\circ} \mathrm{N}$, Barrow,

Alaska

Interior tundra,

$79^{\circ} \mathrm{N}$, Axel

Heiberg Island
Summer

N

S L

164

153

$\begin{array}{ll}-68 & -78\end{array}$

$-70 \quad-76$

-18
$(\mathrm{G}+\mathrm{M})$

104

$\begin{array}{ll}-41 & -34\end{array}$

86

$\begin{array}{ll}-29 & -40\end{array}$

Snow and ice-covered in summer

Ablation zone, 68

McCall Glacier,

$69^{\circ} \mathrm{N}$

Accumulation zone, 20

White Glacier,

$79^{\circ} \mathrm{N}$

Greenland ice cap, 9

$70^{\circ} \mathrm{N}$

Thin sea ice $(<5 \mathrm{~cm})$

Thick sea ice $(>3 \mathrm{~m})$

Central Arctic

Ocean (climato-

logical average)
$24 \rightarrow$

282

$29 \quad-20$

$\begin{array}{lll}74 & -6 & -7\end{array}$ $\rightarrow \quad-20$
Winter

$\begin{array}{llllll}N & S & \text { L } & \text { G } & \text { M }\end{array}$

$-22$

$\begin{array}{cccc}-32 & 32 & -2 & (G+M) \\ & & & 2\end{array}$

2

$-17 \quad 14$

Antarctic coast:

Mawson and

Adélie Land

Interior ice shee

Vostok, South

Pole, Plateau

\begin{tabular}{|c|c|c|c|c|c|c|}
\hline 31 & \multicolumn{3}{|c|}{$\begin{array}{c}-25 \\
(L+G+M)\end{array}$} & -41 & 7 & $\begin{array}{c}34 \\
G+M)\end{array}$ \\
\hline 20 & $\begin{array}{c}-18 \\
(\mathrm{~S}+\mathrm{L})\end{array}$ & -2 & 0 & -19 & $\begin{array}{c}-17 \\
(\mathrm{~S}+\mathrm{L})\end{array}$ & 2 \\
\hline
\end{tabular}

Source of data

Ohmura (1981)

Ohmura (1981)

Wendler (1971)

Mather and Thornthwaite (1956, 1958); Maykut and Church (1973); Weller and Holmgren (1974)

Ohmura (1981)

Wendler and Weller (1974)

Havens (1964); Ohmura (1981)

Ambach (1963)

Maykut (1986)

Maykut (1986)

Vowinckel and Orvig (1964) 


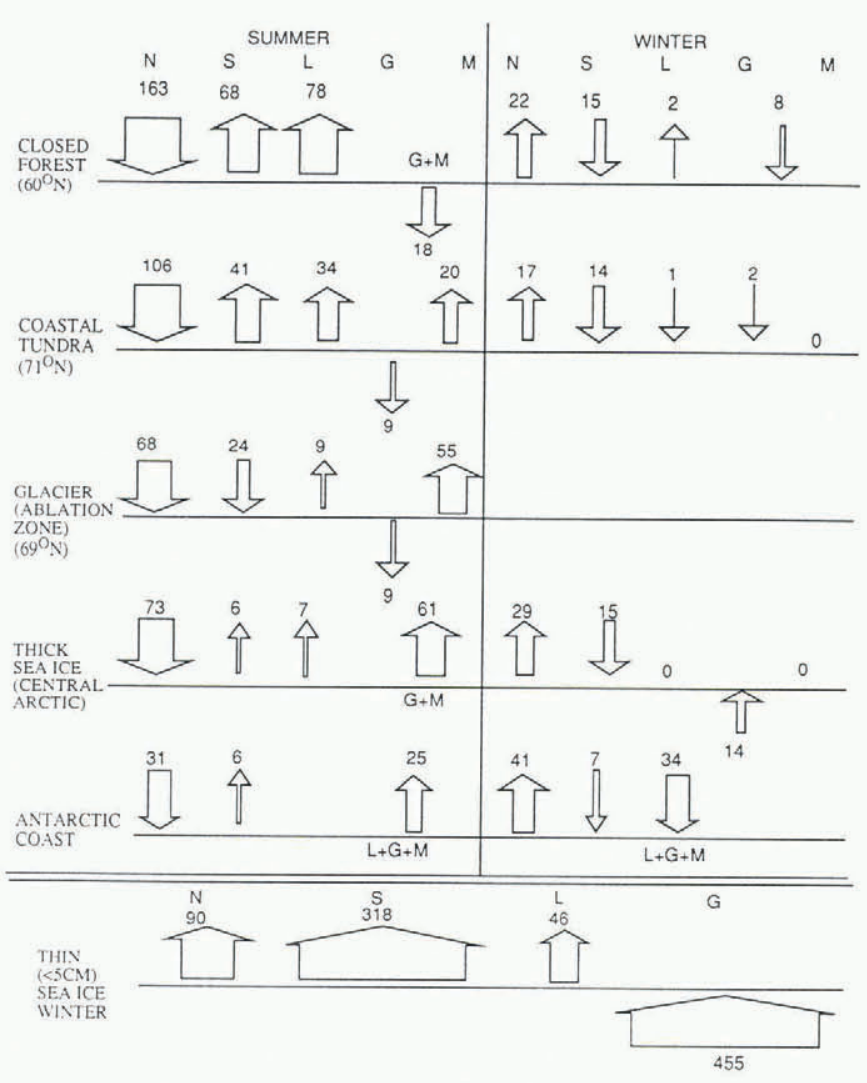

Fig. 3. Energy balance over various terrain types in the polar regions $\left(\mathrm{W} \mathrm{m}^{-2}\right)$.

very small. For the Antarctic, the largest local heat source in summer is the surrounding open ocean. Glacier surfaces close to the Arctic and Antarctic coasts receive similar amounts of radiative energy, but the differences in the radiation budgets of the Arctic and Antarctic hinterlands are enormous, with the Arctic receiving an order of magnitude more energy than the Antarctic.

In winter, the energy balances of almost all polar terrain types and surfaces are very similar, since all terrains are covered by snow, and the incoming solar radiation is small or zero. Two exceptions are thin ice and open water leads (the latter usually freeze quickly in winter and there is probably no large area of open water in the Arctic Ocean in winter at any time). The sensible heat energy available to the atmosphere from the ocean through these areas of thin ice is on the order of $300 \mathrm{~W} \mathrm{~m}^{-2}$, a very large amount, even when compared with the sensible heat flux in boreal forests in summer.

\section{TERRAIN PARAMETERS AS INDICATORS OF CLIMATE CHANGE}

Numerical climate models predict a large amplification of the greenhouse effect at high latitudes (Manabe and Stauffer, 1979), due primarily to polar feedback processes. But temperature observations analyzed by Jones (1988) so far only show a very patchy pattern of changes over the last 20 years in the northern hemisphere. Can these patterns be explained by changes in the regional energy balances, which in turn are functions of the corresponding terrain parameters and, if so, what terrain parameters might be most useful for this purpose?

The different polar terrains are characterized by surface and subsurface parameters which largely determine the energy balances of the various terrains. The most crucial of these parameters is the albedo, A, or reflectivity of the surface, which varies widely between different terrains, and between summer and winter (Table II). The emissivity of most natural surfaces influences the outgoing longwave radiation, but differences in emissivity in the polar regions between terrains and seasons are negligible, and therefore not listed. The turbulent transfer of eddy sensible and latent heats is affected by the roughness of the surface, expressed as a roughness parameter, $z_{0}$, and the subsurface heat flux is affected by the thermal diffusivity, $\mathrm{K}$, of the substrata.

Changes in the polar regions' snow and ice cover will have far-reaching effects on the surface characteristics and climate, and vice versa. Foster (1989) has documented systematically earlier spring break-up dates of the snow cover on the North Slope of Alaska over the last 40 years. This is consistent with the temperature increase in Alaska reported by Jones (1988). The dramatic climate effects of feedback between terrain parameters, particularly albedo, energy balance, and air temperature during spring break-up in northern Alaska have been documented by Weller and Holmgren (1974). Snow and ice extent are crucial in this

\section{TABLE II. THE ENERGY BALANCE-RELATED PARAMETERS OF TYPICAL ARCTIC TERRAINS}

Terrain parameters

\section{Forest}

Albedo, $\mathrm{A}(\%)$

Summer

Winter

$$
\begin{array}{r}
5-20 \\
30-60
\end{array}
$$

$10-15$

$80-85$

Roughness length, $20(\mathrm{~cm})$

Summer

100

10

$2-4$

0.03

0.003 (soil)

0.004 (snow)

0.003

Boreal forest, primarily spruce, in most areas underlain by permaf rost.

$0.002-0.005$

Terrain types

Tundra

Glaciers

Sea ice

Thermal diffusivity of

Summer

0.012 (ice)

35-45 (bare ice)

80-85

$30-70$

$80-85$

0.24 (bare ice)

0.09

Wet flat coastal tundra, plus better-drained tundra in upland rolling terrain, both underlain

by permaf rost.
0.008 (wet snow)

0.004 (dry snow)

Isolated mountain glaciers in Alaska and elsewhere, plus small ice caps in N. Canada.
0.011

0.004

Annual ice on continental shelves, multiyear ice in central Arctic Ocean with an average thickness of $3-4 \mathrm{~m}$

Sources: Deacon, 1953; Untersteiner and Badgley, 1965; Weller, 1968; Weller and Holmgren, 1974; Wendler and Weller, 1974; Outcalt and others, 1975; Maykut, 1986; Wendler and others, 1988. 
feedback process. Sea-ice extent in the Arctic, for example, has decreased somewhat (Gloersen and Campbell, 1988), which is also consistent with the observed warming of the northern hemisphere. Regional changes, however, are difficult to match in detail with the temperature anomaly patterns of Jones (1988). Changes in both the general circulation and the regional energy balances will have to be considered to explain those patterns. Nevertheless, terrain conditions remain useful integrators of climate change, and better qualification and long-term monitoring of terrain parameters in space and time is desirable to study climate feedbacks.

\section{ACKNOWLEDGEMENT}

This study was in part supported by the Alaska Climate Research Center.

\section{REFERENCES}

Ambach, W. 1963. Untersuchungen zum Energieumsatz in der Ablationszone des grönländischen Inlandeises. Medd. Gronl., 174(4).

Carroll, J.J. 1982. Long-term means and short-term variability of the surface energy balance components at the South Pole. J. Geophys. Res., 87(C6), 4277-4286.

Dalrymple, P., H. Lettau, and S. Wollaston. 1966. South Pole micrometeorological program: data analysis. Antarct. Res. Ser., 9, 13-57.

Deacon, E.L. 1953. Vertical profiles of mean wind in the surface layers of the atmosphere. Geophys. Memoirs, 11(91).

Foster, J.L. 1989. The significance of the date of snow disappearance on the Arctic tundra as a possible indicator of climate change. Arct. Alp. Res., 21(1), 60-70.

Gloersen, P. and W.J. Campbell. 1988. Variations in the Arctic, Antarctic, and global sea ice covers during 1978-1987 as observed with the Nimbus 7 scanning multichannel microwave radiometer. J. Geophys. Res., 93(C9), 10,666-10,674.

Havens, J.M. 1964. Meteorology and heat balance on the accumulation area, McCall Ice Cap, Canadian Arctic Archipelago-summer 1960 (Upper Ice Station 1: $79^{\circ} 41^{\prime} \mathrm{N}, 90^{\circ} 27^{\prime} \mathrm{W}, 1530 \mathrm{~m}$ ). Montreal, McGill University. (Axel Heiberg Island Research Reports. Meteorology 2.)

Jones, P.D. 1988. Hemispheric surface air temperature variations. Recent trends and an update to 1987. J. Climate, 1, 654-660.

Manabe, S. and R.J. Stouffer. 1979. A $\mathrm{CO}_{2}$-climate sensitivity study with a mathematical model of the climate. Nature, 282, 491-493.

Mather, J.R. and C.W. Thornthwaite. 1956. Microclimatic investigations at Point Barrow, Alaska, 1956. Publ. Climatol., 9(1).
Mather, J.R. and C.W. Thornthwaite. 1958. Microclimatic investigations at Point Barrow, Alaska, 1957-1958. Publ. Climatol., 11(2), 61-239.

Maykut, G.A. 1986. The surface heat and mass balance. In Untersteiner, N., ed. The geophysics of sea ice. New York, Plenum Press, 395-463.

Maykut, G.A. and P.E. Church. 1973. Radiation climate of Barrow, Alaska, 1962-66. J. Appl. Meteorol., 12(4), 620628.

Ohmura, A. 1981. Climate and energy balance on Arctic tundra. Axel Heiberg Island, Canadian Arctic Archipelago, spring and summer 1969, 1970 and 1972. Zürich, Eidgenössische Technische Hochschule. Geographisches Institut. (Zürcher Geographische Schriften 3.)

Outcalt, S.I., C. Goodwin, G. Weller, and J. Brown. 1975. A digital computer simulation of the annual snow and soil thermal regimes at Barrow, Alaska. Water Resour. Res., 11, 709-715.

Roulet, R.R. 1969. Radiation regime of Arctic drifting station ARLIS II, January 1964-May 1965. Seattle, WA University of Washington. Department of Atmospheric Sciences.

Rusin, N.P. 1964. Meteorological and radiational regime of Antarctica. Jerusalem, Israel Program for Science Translations.

Schwerdtfeger, W. 1984. Weather and climate of the Antarctic. Amsterdam, Elsevier. (Developments in Atmosphere Science 15.)

Untersteiner, N. and F.I. Badgley. 1965. The roughness parameters of sea ice. J. Geophys. Res., 70(18), 4573-4577.

Vowinckel, E. and S. Orvig. 1964. Energy balance of the Arctic, the heat budget over the Arctic Ocean. Arch Meteorol. Geophys. Bioklimatol., Ser. B, 14(3-4), 303-325.

Weaver, D.F. 1969. Radiation regime over Arctic tundra 1965. Seattle, WA, University of Washington. Department of Atmospheric Sciences.

Weller, G. 1968. Heat-energy transfer through a four-layer system: air, snow, sea ice, sea water. J. Geophys. Res., 73(4), 1209-1220.

Weller, G. 1980. Spatial and temporal variations in the south polar surface energy balance. Mon. Weather Rev., 108(12), 2006-2014.

Weller, G. and B. Holmgren. 1974. The microclimates of Arctic tundra. J. Appl. Meteorol., 13(8), 854-862.

Wendler, G. 1971. An estimate of the heat balance of a valley and hill station in central Alaska. J. Appl. Meteorol., 10(4), 684-693.

Wendler, G. and G. Weller. 1974. A heat-balance study on McCall Glacier, Brooks Range, Alaska: a contribution to the International Hydrological Decade. J. Glaciol., 13(67), 13-26.

Wendler, G., N. Ishikawa, and Y. Kodama. 1988. The heat balance of ice slope of Adélie Land, eastern Antarctica. J. Appl. Meteorol., 27(1), 52-65. 